From the Department of Obstetrics \& Gynecology, University Hospital Gasthuisberg, Katholieke Universiteit, Leuven; National Alliance of Christian Sickness Funds; Belgian Cancer Registry, Brussels; Obstetrics and Gynecology, Université Catholique de Louvain, Louvain-la-Neuve, Belgium; Department of Medical Oncology, Radboud University Nijmegen Medical Centre, Nijmegen, The Netherlands; Department of Obstetrics and Gynecology, Charles University, Prague, Czech Republic.

Submitted March 25, 2009; accepted August 6, 2009; published online ahead of print at www.jco.org on October 19 2009

Supported by Research FoundationFlanders (FWO) Project G. 0358.06 (F.A. and K.V.C.), Stichting tegen kanker Project SCIE2006-17, Research FundKatholieke Universiteit, and Clinical Research Fund-UZ Gasthuisberg.

Authors' disclosures of potential conflicts of interest and author contributions are found at the end of this article.

Clinical Trials repository link available on JCO.org.

Corresponding author: Frédéric Amant, $\mathrm{MD}, \mathrm{PhD}$, Obstetrics and Gynecology,

University Hospital Gasthuisberg, Herestraat 49, 3000 Leuven, Belgium; e-mail: frederic.amant@uz.kuleuven.be.

() 2009 by American Society of Clinical Oncology

0732-183X/10/2804-683/\$20.00

DOI: $10.1200 / J C 0.2009 .23 .2801$

\title{
Cancer During Pregnancy: An Analysis of 215 Patients Emphasizing the Obstetrical and the Neonatal Outcomes
}

Kristel Van Calsteren, Liesbeth Heyns, Frank De Smet, Liesbet Van Eycken, Mina Mhallem Gziri, Willemijn Van Gemert, Michael Halaska, Ignace Vergote, Nelleke Ottevanger, and Frédéric Amant

\section{$\begin{array}{lllllllll}\text { A } & \text { B } & \text { S } & \text { T } & \text { R } & \text { A } & \text { C } & T\end{array}$}

\section{Purpose}

The aim of this study was to assess the management and the obstetrical and neonatal outcomes of pregnancies complicated by cancer.

\section{Patients and Methods}

In an international collaborative setting, patients with invasive cancer diagnosed during pregnancy between 1998 and 2008 were identified. Clinical data regarding the cancer diagnosis and treatment and the obstetric and neonatal outcomes were collected and analyzed.

\section{Results}

Of 215 patients, five (2.3\%) had a pregnancy that ended in a spontaneous miscarriage and 30 $(14.0 \%)$ pregnancies were interrupted. Treatment was initiated during pregnancy in $122(56.7 \%)$ patients and postpartum in $58(27.0 \%)$ patients. The most frequently encountered cancer types were breast cancer (46\%), hematologic malignancies (18\%), and dermatologic malignancies $(10 \%)$. The mean gestational age at delivery was $36.3 \pm 2.9$ weeks. Delivery was induced in $71.7 \%$ of pregnancies, and $54.2 \%$ of children were born preterm. In the group of patients prenatally exposed to cytotoxic treatment, the prevalence of preterm labor was increased $(11.8 \%$; $P=.012)$. Furthermore, in this group a higher proportion of small-for-gestational-age children (birth weight below 10th percentile) was observed $(24.2 \% ; P=.001)$. Of all neonates, $51.2 \%$ were admitted to a neonatal intensive care unit, mainly $(85.2 \%)$ because of prematurity. There was no increased incidence of congenital malformations.

\section{Conclusion}

Pregnant cancer patients should be treated in a multidisciplinary setting with access to maternal and neonatal intensive care units. Prevention of iatrogenic prematurity appears to be an important part of the treatment strategy.

\section{J Clin Oncol 28:683-689. (C) 2009 by American Society of Clinical Oncology}

\section{INTRODUCTION}

Cancer treatment during pregnancy is a challenge. Although surgery has been shown to be safe during pregnancy, ${ }^{1,2}$ only a few drugs have been tested in pregnant women. Hence, most drugs are classified as "contraindicated during pregnancy, unless strictly needed." 3 Therefore, physicians must assess whether the benefits of treatment for the mother outweigh the potential risk to the fetus.

Chemotherapy and radiotherapy were long considered incompatible with normal fetal development. This policy resulted in either termination of pregnancy or suboptimal cancer treatment for the mother. Clinicians have gained some experience in this field from case reports and small studies. In contrast to previous assumptions, the short-term outcome after prenatal exposure to chemotherapy or radiotherapy initiated after the first gestational trimester appears to be positive. ${ }^{4-7}$ Studies on the long-term outcome of prenatal exposure to chemotherapy show a reassuring outcome for the children. ${ }^{8,9}$ However, because the described or applied methodology in these studies was rather poor, additional research is necessary.

The concurrence of cancer and pregnancy is a relatively rare problem, occurring in about one in 1,000 pregnancies. $^{10}$ Therefore, single institutional or regional initiatives will not be able to provide sufficient information on the safety of cancer treatment during pregnancy for both the mother and fetus. Since more women are delaying childbearing and the incidence of cancer in the 30 to 49 years age group is increasing, it can be expected that in the future, cancer will be diagnosed more often in pregnant women. ${ }^{11,12}$ To gain more data and obtain better counseling for the patient, the need for a multicenter registration is growing. ${ }^{13}$ Therefore, we 
initiated an international collaborative study investigating the problem of cancer during pregnancy. In this study, we focus on management options and the impact on the obstetric and neonatal outcomes.

\section{PATIENTS AND METHODS}

In an international collaborative setting, patients with invasive cancer diagnosed during pregnancy were identified. Patients with a preinvasive disease were excluded. To ensure uniformity in obstetric and oncologic management, patients diagnosed before 1998 were excluded in the current analyses. The study was approved by the institutional review board in the University Hospitals of Leuven, Belgium; Nijmegen, the Netherlands; and Prague, Czech Republic.

Because information on pregnant state is not available in most cancer registries and because oncologic problems are not registered in perinatal data sets, we attempted to contact as many physicians who treat pregnant cancer patients as possible by means of networking (eg, mailing members of the Flemish Society of Obstetrics and Gynecology); newsletters; presentations at congresses for obstetricians, hematologists, or oncologists; and a Web site (www.cancerinpregnancy.org). We asked physicians to register the patients they treat or had treated and to trace patients by means of their institutional data sets and hospital registration systems.

In Belgium, a collaboration was established with the Foundation Cancer Registry and one medical insurance organization (National Alliance of Christian Sickness Funds). Registration codes for chemotherapy and radiotherapy were linked to the code for delivery or in utero death ( $>16$ weeks of gestation) with a maximum time interval of 9 months between both. The list of patients we obtained was fine-tuned in such a way that only the patients with a cancer diagnosis during pregnancy remained. Treating physicians of these patients were contacted by the Foundation Cancer Registry with a request to register their patients anonymously in this study.

Clinical data were collected and analyzed in accordance with local privacy legislation. Oncologic, obstetric, and pediatric files were screened to retrieve clinical information. Oncologic data included the type of cancer, the date of diagnosis, and the type and date of treatment. Obstetric data we attempted to retrieve included gestational age at diagnosis, obstetric complications, gestational age at delivery, and mode of delivery (induction, cesarean

\begin{tabular}{|lrc|}
\hline \multicolumn{3}{c}{ Table 1. Distribution of Tumor Types } \\
\hline \multicolumn{1}{c}{ Tumor Type } & No. & $\%$ \\
\hline Breast cancer & 99 & 46 \\
Hematologic malignancies & 40 & 18 \\
Hodgkin's disease & 13 & 6.0 \\
Non-Hodgkin's lymphoma & 10 & 4.7 \\
Acute lymphatic leukemia & 4 & 1.9 \\
Acute myelogenous leukemia & 7 & 3.2 \\
Chronic myelogenous leukemia & 4 & 1.9 \\
Hairy cell leukemia & 1 & 0.5 \\
Multiple myeloma & 1 & 0.5 \\
Dermatologic malignancies & 21 & 10 \\
Basal cell carcinoma & 9 & 4.2 \\
Melanoma & 11 & 5.1 \\
Kaposi's sarcoma & 1 & 0.5 \\
Cervical cancer & 17 & 8 \\
Brain tumor & 8 & 4 \\
Ovarian cancer & 8 & 4 \\
Colorectal cancer & 5 & 2 \\
Other (sarcoma, lung, liver, kidney, Gl stromal tumor, & 17 & 8 \\
thyroid, urachus, rhinopharyngeal) & 215 & 100 \\
\hline Total & & \\
\hline
\end{tabular}

section, spontaneous labor). Pediatric data collected included birth weight, sex, congenital malformations, admission to neonatal intensive care unit (NICU), and reason for admission.

All data were collected in a Microsoft Access database and processed in Microsoft Excel 2007 (Microsoft, Redmond, WA). Unless mentioned otherwise, values are reported as mean \pm standard deviation. Statistical testing was performed with Graphpad Prism 5 and its online software (http:// www.graphpad.com/quickcalcs/index.cfm). Two-sided tests were applied. The Wilcoxon rank sum test was used for comparing continuous variables in two groups; for more than two groups, the Kruskal-Wallis exact test was used. A binomial exact test was used for comparing a proportion with an expected value. Results were considered significant at $P<.05$.

\section{RESULTS}

Between 1998 and 2008, 215 patients with a diagnosis of cancer during pregnancy were registered. The distribution by country was 147 (68.4\%) in Belgium, 55 (25.6\%) in the Netherlands, and 13 (6.0\%) in the Czech Republic. The maternal age at diagnosis was $33.2 \pm 4.8$ years and the gestational age was $21.0 \pm 10.8$ weeks. The timing of cancer diagnosis in pregnancy was distributed as follows: $52(24.2 \%)$ in the

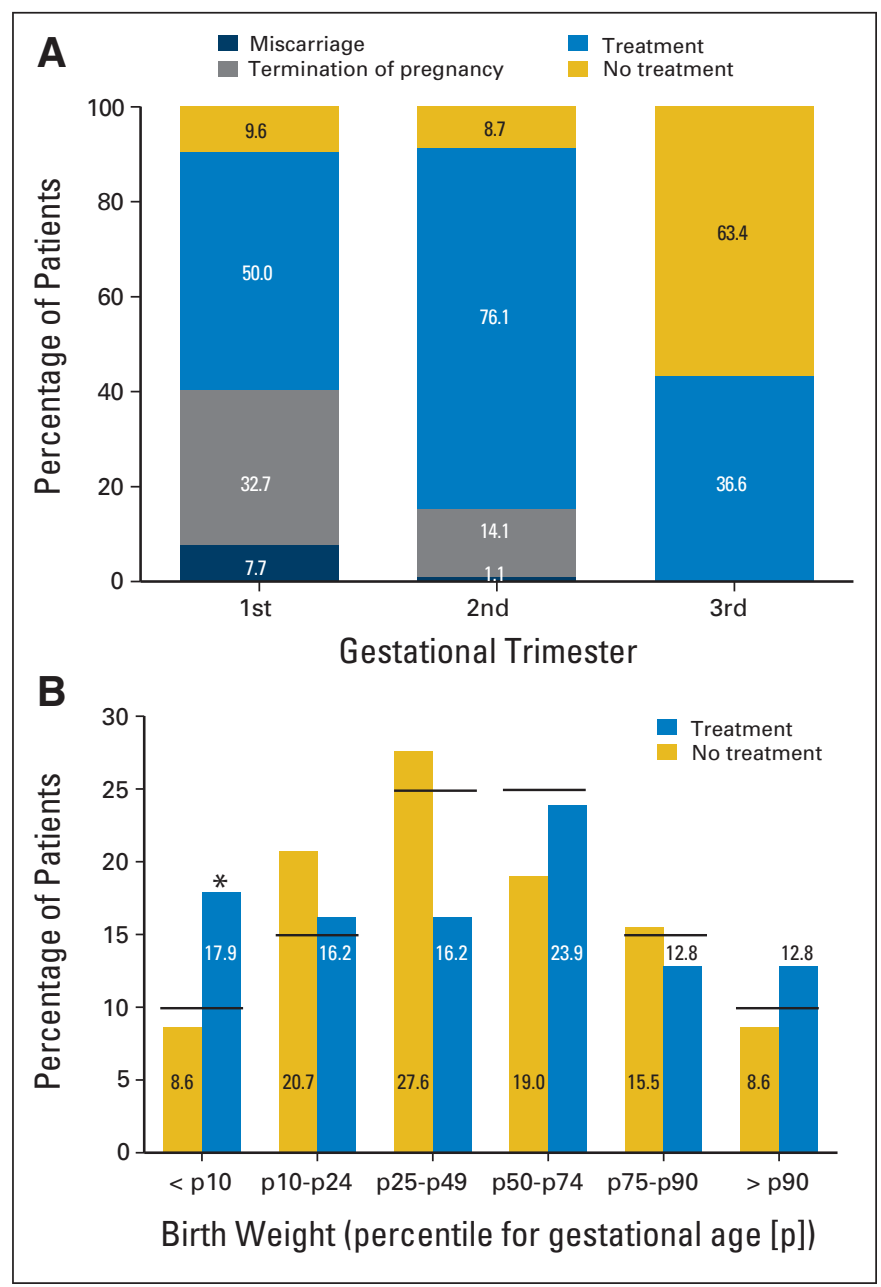

Fig 1. (A) Management of cancer during pregnancy per trimester $(n=215)$. (B) Distribution of birth weight $(n=175)$ expressed in percentile for gestational age (p) $\left({ }^{*} P=.012\right)$. 
first trimester, $92(42.8 \%)$ in the second trimester, and $71(33.0 \%)$ in the third trimester.

\section{Oncologic Problems}

The distribution of cancer types is depicted in Table 1 . The most frequently encountered tumor types were breast cancer (46\%), hematologic malignancies (18\%), and dermatologic malignancies (10\%). Primary and recurrent cancer were diagnosed in 204 and 11 patients, respectively.

\section{Treatment Policy Related to Pregnancy}

In five $(2.3 \%)$ of 215 patients, a miscarriage occurred at $10.7 \pm$ 4.8 weeks of gestation, before cancer treatment was started. In 30 (14.0\%) of 215 patients, the pregnancy was terminated at a gestational age of $10.9 \pm 6.8$ weeks. In 13 patients $(43.3 \%)$, pregnancy termination occurred after a gestational age of 13 weeks. In 29 of 30 patients, maternal cancer was the reason for termination. In only one patient, the pregnancy was unwanted. In $58(27.0 \%)$ of 215 patients, treatment was delayed until postpartum. Here, the cancer diagnosis was made at a gestational age of $30.6 \pm 9.4$ weeks. In 122 (56.7\%) of 215 patients, a single or a combination of treatment modalities was initiated during pregnancy after a cancer diagnosis at a gestational age of $19.6 \pm 8.5$ weeks. The distribution of therapies used during pregnancy was as follows: $40.2 \%$ surgery $(\mathrm{n}=49), 27.0 \%$ chemotherapy $(\mathrm{n}=33)$, $20.5 \%$ surgery and chemotherapy $(\mathrm{n}=25), 2.6 \%$ radiotherapy $(\mathrm{n}=3), 2.5 \%$ surgery and radiotherapy $(\mathrm{n}=3), 2.5 \%$ surgery, chemotherapy, and radiotherapy $(n=3), 1.6 \%$ interferon $(n=2), 0.8 \%$ chemotherapy and radiotherapy $(n=1), 0.8 \%$ cryotherapy $(n=1)$, $0.8 \%$ hormonal therapy $(\mathrm{n}=1)$, and $0.8 \%$ monoclonal antibody $(\mathrm{n}=1)$. A total of 62 women received chemotherapy and 10 received radiotherapy (Appendix Table A1, online only). The management per gestational trimester is shown is Figure 1A.

\section{Obstetric Outcomes}

For the processing of obstetric data, miscarriages $(n=5)$ and abortions $(\mathrm{n}=30)$ were excluded, leaving 180 pregnancies for further analysis. In 27 (15\%) of 180 patients, a gestational complication was registered. The distribution per treatment group is depicted in Table 2 . When compared with preterm premature rupture of membranes (PPROM) and preterm labor incidences in the normal population (PPROM, 3\%; spontaneous preterm labor, 4\%), ${ }^{14}$ no increase was seen (PPROM, three [1.7\%] of $180 ; P=$ not significant, and preterm labor, eight [4.4\%] of $180 ; P=.864$ [binomial test]). However, a subanalysis for the patients exposed to chemotherapy and/or radiotherapy revealed a significant increase in preterm labor (eight [11.8\%] of $68 ; P=.012$ [binomial test]), but not of PPROM (three [4.4\%] of $68 ; P=.668$ [binomial test]). These findings were even more pronounced looking only at chemotherapy-exposed pregnancies (preterm labor, eight [12.9\%] of $62 ; P=.006$, and PPROM, three [4.8\%] of $62 ; P=.568$ [binomial test]).

Table 3 shows the distribution of the different types of labor and the gestational age at delivery related to the oncologic treatment. Induction of labor or an elective cesarean section was performed in $71.7 \%(n=129)$ of the pregnancies at a mean gestational age of $35.6 \pm$ 2.8 weeks. Maternal cancer was the indication for induction/cesarean section in $76.7 \%$ of these pregnancies (oncologic reasons, $\mathrm{n}=99$; obstetric reasons, $\mathrm{n}=21$; unknown, $\mathrm{n}=9$ ).

\begin{tabular}{|c|c|c|c|c|}
\hline Treatment Group & No. & $\%$ & Complications & $\begin{array}{c}\text { Gestational Age at Diagnosis } \\
\text { (weeks; + days after treatment) }\end{array}$ \\
\hline No treatment $(n=58)$ & 6 & 10.3 & $\begin{array}{l}\text { PIH }(n=2) \\
\text { Preeclampsia }(n=1) \\
\text { Gestational cholestasis }(n=1) \\
\text { Preterm contractions }(n=1) \\
\text { Antepartum bleeding }(n=1)\end{array}$ & $\begin{array}{l}35.4, N A \\
\text { NA } \\
33.5 \\
36.0 \\
23.4\end{array}$ \\
\hline Chemotherapy ( $\mathrm{n}=33$ ) & 13 & 39.4 & $\begin{array}{l}\text { Gestational diabetes }(n=1) \\
\text { Preterm contractions* }(n=2) \\
\text { PPROM }(n=3) \\
\text { Sepsis }(n=1) \\
\text { Preterm labor }(n=6)\end{array}$ & $\begin{array}{l}29.6 \\
31.0(+0), 31.5(+0) \\
28.0(+10), 32.5(+35), 34.4(+10) \\
26.2(+0) \\
28.0(+11), 32.2(+2), 33.1(+11), 34.4(+8), 36.0 \\
\quad(+20), 36.5(+21)\end{array}$ \\
\hline Chemotherapy + surgery $(n=25)$ & 4 & 16.0 & $\begin{array}{l}\text { Preterm contractions* }(n=1) \\
\text { Sepsis }(n=1) \\
\text { Preterm labor }(n=2)\end{array}$ & $\begin{array}{l}27.0 \text { (+0 after surgery) } \\
26.0 \text { (+1 after chemotherapy) } \\
34.0,34.3 \text { (+34 and } 59 \text { after chemotherapy) }\end{array}$ \\
\hline Surgery ( $n=49$ ) & 3 & 6.1 & $\begin{array}{l}\text { IUGR }(n=1) \\
\text { Preterm contractions }(n=1) \\
\text { Sepsis }(n=1)\end{array}$ & $\begin{array}{l}\text { NA } \\
30 \text { (NR) } \\
35.3 \text { (NR) }\end{array}$ \\
\hline Radiotherapy ( $n=3$ ) & 1 & 33.3 & IUGR (n = 1) & $28(+10)$ \\
\hline Chemotherapy + radiotherapy $(n=1)$ & 0 & 0.0 & & \\
\hline Radiotherapy + surgery $(n=3)$ & 0 & 0.0 & & \\
\hline Surgery + chemotherapy + radiotherapy $(n=3)$ & 0 & 0.0 & & \\
\hline Others $(n=5)$ & 0 & 0.0 & & \\
\hline Total & 27 & 15.0 & & \\
\hline
\end{tabular}




\begin{tabular}{|c|c|c|c|c|c|c|c|c|c|}
\hline \multirow[b]{2}{*}{ Labor } & \multicolumn{3}{|c|}{ All Pregnancies } & \multicolumn{3}{|c|}{ No Treatment During Pregnancy } & \multicolumn{3}{|c|}{ Treatment During Pregnancy } \\
\hline & $\begin{array}{c}\text { No. of } \\
\text { Pregnancies }\end{array}$ & $\%$ & $\begin{array}{l}\text { Gestational Age } \\
\text { (mean No. of } \\
\text { weeks } \pm \text { SD) }\end{array}$ & $\begin{array}{c}\text { No. of } \\
\text { Pregnancies }\end{array}$ & $\%$ & $\begin{array}{l}\text { Gestational Age } \\
\text { (mean No. of } \\
\text { weeks } \pm \text { SD) }\end{array}$ & $\begin{array}{c}\text { No. of } \\
\text { Pregnancies }\end{array}$ & $\%$ & $\begin{array}{c}\text { Gestational Age } \\
\text { (mean No. of } \\
\text { weeks } \pm \text { SD) }\end{array}$ \\
\hline Spontaneous & 41 & 22.8 & $38.3 \pm 2.4$ & 12 & 20.7 & $39.3 \pm 1.1$ & 29 & 23.8 & $37.8 \pm 2.7$ \\
\hline Induction & 66 & 36.7 & $36.5 \pm 2.3$ & 18 & 31.0 & $37.0 \pm 2.8$ & 48 & 39.3 & $36.4 \pm 2.1$ \\
\hline Elective cesarean section & 63 & 35.0 & $34.7 \pm 2.9$ & 25 & 43.1 & $35.1 \pm 3.1$ & 38 & 31.1 & $34.4 \pm 2.8$ \\
\hline Unknown & 10 & 5.6 & - & 3 & 5.2 & - & 7 & 5.7 & - \\
\hline Total & 180 & & $36.3 \pm 2.9$ & 58 & & $36.7 \pm 3.1$ & 122 & & $36.1 \pm 2.8$ \\
\hline
\end{tabular}

Abbreviation: SD, standard deviation.

\section{Neonatal Outcome}

Data on the gestational age at delivery were available for 179 of the 185 children -180 pregnancies, with three twins and one triplet. The mean gestational age at delivery was $36.2 \pm 2.9$ weeks. Delivery occurred for $15(8.4 \%)$ of 179 children before 32 weeks of gestation, for $82(45.8 \%)$ of 179 children between 32 and 37 weeks of gestation, and for $82(45.8 \%)$ of 179 children at term ( $\geq 37$ weeks). For the 97 preterm children, labor started spontaneously in eight pregnancies $(8.2 \%)$, and induction of labor/cesarean section was performed in 87 $(89.7 \%)$ with two unknown $(2.1 \%)$. The indication for induction of labor/cesarean section was maternal cancer for $88 \%$, whereas there were obstetric indications for delivering the baby preterm in $12 \%$.

Data on the birth weight of 175 children were available (166 children from singleton pregnancies, six children from three twin pregnancies, and three children from one triplet pregnancy). In 26 of 175 children, the birth weight was below the 10th percentile for gestational age (14.9\%; $P=.054$ [binomial test]). A subanalysis of this group (Table 4 ) shows a large proportion of small-for-gestational-age children (birth weight below 10th percentile) and children who have hematologic tumors (nine [27.3\%] of 33).

Binomial testing revealed a significant increase in small-forgestational-age children in the group receiving treatment during pregnancy $(\mathrm{n}=21[17.9 \%]$ of $117 ; P=.012)$ versus not treated in pregnancy ( $\mathrm{n}=5[8.6 \%]$ of $58 ; P=$ not significant). The distribution of the birth weight expressed by percentile for gestational age in the group with and without treatment during pregnancy is presented in Figure 1B. Looking specifically at cytotoxic treatment (chemotherapy and/or radiotherapy), small-for-gestational-age babies were seen in 16 (24.2\%) of 66 pregnancies $(P=.001$ [binomial test]) versus $10(9.2 \%)$ of 109 in pregnancies without cytotoxic treatment $(P=$ not significant [binomial test]).

The patients in the chemotherapy group who had children with a birth weight below the 10th percentile were treated for acute myelogenous leukemia $(\mathrm{n}=3)$, acute lymphatic leukemia $(\mathrm{n}=1)$, breast cancer $(\mathrm{n}=3)$, Hodgkin's disease $(\mathrm{n}=2)$, and non-Hodgkin's lymphoma $(\mathrm{n}=1)$; the patients receiving chemotherapy and surgery were treated for ovarian cancer $(\mathrm{n}=2)$, breast cancer $(\mathrm{n}=1)$, and colon carcinoma $(n=1)$. Small-for-gestational-age children of the two patients exposed to radiotherapy were treated for non-Hodgkin'slymphoma and sarcoma.

Data on the outcome of 175 neonates were available for analysis. A physical abnormality was diagnosed in 13 children at birth (Table 5). Compared with the background risk of major malformations of $4.1 \%$ to $6.9 \%$ and risk of minor malformations of $6.5 \%$ to $35.8 \%,{ }^{15-17}$ these data do not show an increased incidence of physical malformations at birth. Major and minor malformations were observed in

\begin{tabular}{|c|c|c|c|c|c|c|c|}
\hline \multirow[b]{2}{*}{ Tumor Type } & \multicolumn{7}{|c|}{ Birth Weight Below 10th Percentile } \\
\hline & No. & Total No. & $\%$ & Treatment During Pregnancy & No. & Total No. & $\%$ \\
\hline Acute lymphatic leukemia & 1 & 3 & 33.3 & Chemotherapy & 10 & 33 & 30.3 \\
\hline Acute myelogenous leukemia & 4 & 5 & 80.0 & Surgery + chemotherapy & 4 & 25 & 16.0 \\
\hline Hodgkin's disease & 2 & 11 & 18.2 & Surgery + radiotherapy & 1 & 2 & 50 \\
\hline Non-Hodgkin's disease & 2 & 9 & 22.2 & Surgery & 5 & 46 & 10.9 \\
\hline Breast cancer & 6 & 82 & 7.3 & Chemotherapy + radiotherapy & 0 & 1 & 0 \\
\hline Cervical cancer & 2 & 15 & 13.3 & Chemotherapy + radiotherapy + surgery & 0 & 3 & 0 \\
\hline GI cancer & 2 & 4 & 50.0 & Other treatments & 0 & 5 & 0 \\
\hline Brain tumor & 2 & 9 & 22.2 & & & & \\
\hline Ovarian cancer & 2 & 8 & 25.0 & & & & \\
\hline Skin tumor & 2 & 16 & 12.5 & & & & \\
\hline
\end{tabular}




\begin{tabular}{|c|c|c|c|c|c|c|}
\hline $\begin{array}{l}\text { Treatment During } \\
\text { Pregnancy }\end{array}$ & $\begin{array}{l}\text { Gestational Age at } \\
\text { Treatment (weeks) }\end{array}$ & Treatment Modality & Malformation & $\begin{array}{l}\text { No. of } \\
\text { Children } \\
\text { With } \\
\text { Malformation }\end{array}$ & $\begin{array}{l}\text { Total } \\
\text { No. of } \\
\text { Children }\end{array}$ & $\%$ \\
\hline None & & & $\begin{array}{l}\text { Prader-Willi } \\
\text { Congenital laryngomalacia } \\
\text { Hemangioma }\end{array}$ & 3 & 58 & 5.2 \\
\hline Surgery & $\begin{array}{l}18 \\
32\end{array}$ & $\begin{array}{l}\text { Partial nephrectomy + para-aortic } \\
\text { lymphadenectomy } \\
\text { Mastectomy } \\
\text { Lumpectomy + ALND }\end{array}$ & $\begin{array}{l}\text { Cardial hematomas in tuberous sclerosis } \\
\text { (autosomal dominant genetic disease) } \\
\text { Multiple congenital anomalies } \\
\text { (hypospadias, agenesis of left little } \\
\text { finger, abnormal position of left foot) } \\
\text { Hemangioma }\end{array}$ & 3 & 46 & 6.5 \\
\hline Chemotherapy & $\begin{array}{l}26,29,32 \\
25,29,33 \\
24,28,32\end{array}$ & $\begin{array}{l}\text { AC }(3 \times) \\
\text { MOPP/ABV }(3 \times) \\
\text { HOVON70 }\end{array}$ & $\begin{array}{l}\text { Hip subluxation } \\
\text { Pectus excavatum } \\
\text { Hemangioma }\end{array}$ & 3 & 33 & 9.1 \\
\hline $\begin{array}{r}\text { Chemotherapy + } \\
\text { radiotherapy }\end{array}$ & $\begin{array}{l}\text { RT: } 15-19 \\
\text { CT: } 26,30\end{array}$ & $\begin{array}{l}\text { Mantle field } 40 \text { Gy } \\
\text { MOPP/ABV }(2 \times)\end{array}$ & Bilateral partial syndactyly digiti II-III & 1 & 1 & 100 \\
\hline Surgery + chemotherapy & $\begin{array}{l}\text { S: } 15 \\
\text { S: } 17 \\
\text { CT: } 20,23,26,29,32,35 \\
\text { S: } 17 \\
\text { CT: } 23,26,29,32\end{array}$ & $\begin{array}{l}\text { Lumpectomy } \\
\text { Mastectomy + ALND } \\
\text { FEC }(6 \times) \\
\text { Lumpectomy + ALND } \\
\text { Epirubicin }(4 \times)\end{array}$ & $\begin{array}{l}\text { Bilateral small protuberance on phalanx } 5 \\
\text { Rectal atresia }\end{array}$ & 2 & 25 & 8.0 \\
\hline $\begin{array}{l}\text { Surgery }+ \text { chemotherapy }+ \\
\text { radiotherapy }\end{array}$ & $\begin{array}{l}\text { S: } 7 \\
\text { S: } 9 \\
\text { RT: } 11-21 \\
\text { CT: } 22,25,28\end{array}$ & $\begin{array}{l}\text { Lumpectomy + SND } \\
\text { ALND } \\
\text { Thorax } 50 \text { Gy + boost } 16 \text { Gy } \\
\text { FAC }(3 \times)\end{array}$ & Doubled cartilage ring in both ears & 1 & 3 & 33.3 \\
\hline Radiotherapy & & & & 0 & 2 & 0 \\
\hline Surgery + radiotherapy & & & & 0 & 2 & 0 \\
\hline $\begin{array}{c}\text { Other (hormonal, interferon, } \\
\text { monoclonal antibody) }\end{array}$ & & & & 0 & 5 & 0 \\
\hline $\begin{array}{l}\text { NOTE: Bold: major malforn } \\
\text { Abbreviations: ALND, axilla } \\
1.4 \mathrm{mg} / \mathrm{m}^{2}, \text { procarbazine } 100 \\
\text { (PO; days 1-7), } 40 \mathrm{mg} / \mathrm{m}^{2} \mathrm{P} \\
\text { days } 8,15,22,29,43) \text {; daur } \\
19,22,24,26), \text { mercapto } \\
\text { colony-stimulating factor (G } \\
\text { chemotherapy; S, surgery; } \\
\mathrm{mg} / \mathrm{m}^{2} \text {, doxorubicin } 60 \mathrm{mg} / \mathrm{l}\end{array}$ & 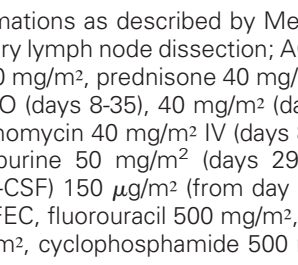 & $\begin{array}{l}\text { erks et al. }{ }^{17} \\
\text { AC, doxorubicin } 60 \mathrm{mg} / \mathrm{m}^{2} \text {, cyclopho } \\
/ \mathrm{m}^{2} \text {, doxorubicin } 25 \mathrm{mg} / \mathrm{m}^{2} \text {, vinblas } \\
\text { lays 8-28), methotrexate } 15 \mathrm{mg} \text { in } \\
8,15,22) ; \text { cyclophosphamide } 1,0 \\
9-49) \text {, methotrexate } 5,000 \mathrm{mg} / \mathrm{m}^{2} \\
\text { absolute neutrophil count [ANC] } \\
\text { epirubicin } 100 \mathrm{mg} / \mathrm{m}^{2} \text {, cyclophos } \\
\mathrm{mg} / \mathrm{m}^{2} \text {. }\end{array}$ & $\begin{array}{l}\text { osphamide } 600 \mathrm{mg} / \mathrm{m}^{2} ; \text { MOPP/ABV, mechlo } \\
\text { stine } 6 \mathrm{mg} / \mathrm{m}^{2} \text {, bleomycin } 10 \mathrm{U} / \mathrm{m}^{2} ; \text { HOVON7 } \\
\text { trathecally (days } 1,8,15,29,43 \text { ), vincristin } \\
\left.00 \mathrm{mg} / \mathrm{m}^{2} \text { IV (day } 8\right), \text { L-asparaginase } 6,000 \\
2 \text { IV (days } 29,43 \text { ), methotrexate } 25 \mathrm{mg} / \mathrm{l} \\
<0.5 \times 10^{9} / \mathrm{L} \text { until ANC }>1.0 \times 10^{9} / \mathrm{L} \text { or } \\
\text { phamide } 500 \mathrm{mg} / \mathrm{m}^{2} \text {; SND, sentinel node dis }\end{array}$ & $\begin{array}{l}\text { rethamine } 6 \mathrm{mg} \\
70 \text {, prednisone } \\
1.5 \mathrm{mg} / \mathrm{m}^{2} \text { in } \\
\mathrm{J} / \mathrm{m}^{2} \mathrm{IV} \text { (days } 8, \\
/ \mathrm{m}^{2} \mathrm{PO} \text { (day } 3 \\
\text { day } 43 \text { ); RT, ra } \\
\text { issection; FAC, }\end{array}$ & $\begin{array}{l}\mathrm{g} / \mathrm{m}^{2}, \text { vincr } \\
60 \mathrm{mg} / \mathrm{m}^{2} \\
\text { travenousl } \\
10,12,15 \\
6), \quad \text { granul } \\
\text { diotherapy } \\
\text { fluorourac }\end{array}$ & $\begin{array}{l}\text { ristine } \\
\text { orally } \\
\text { oly (IV; } \\
5,17 \text {, } \\
\text { locyte } \\
\text { Y; CT, } \\
\text { cil } 500\end{array}$ \\
\hline
\end{tabular}

five $(2.9 \%)$ of 175 and eight $(4.6 \%)$ of 175 neonates, respectively. For the subgroup of patients prenatally exposed to radiotherapy and/or chemotherapy, incidences of malformations were within the normal ranges (major: two [3.0\%] of 66 and minor: five [7.5\%] of 66).

Two children born 10 days after the administration of chemotherapy for maternal acute lymphatic leukemia (cytarabine + mitoxantrone + intrathecal methotrexate and prednisone + methotrexate + vincristine + daunomycin + cyclophosphamide + L-asparaginase + mercaptopurine), suffered from hematologic toxicity (leukopenia and pancytopenia) and needed hematologic growth factors.

Information on admission to an NICU was available for 172 children. Eighty-eight (51.2\%) children were hospitalized in the NICU, and prematurity was the indication for admission in 75 (85.2\%) of 88 children. Furthermore, three children $(3.4 \%)$ were hospitalized because of a congenital anomaly, three (3.4\%) because of dysmaturity, one $(1.1 \%)$ because of respiratory insufficiency, and six $(6.8 \%)$ for observation.
One instance of intrauterine death was reported in a woman suffering from diabetes whose pregnancy was complicated with gestational hypertension. The patient refused a follow-up at a maternal intensive care unit. At 39 weeks, she consulted a gynecologist with loss of fetal movements and an intrauterine death was diagnosed. During the delivery, a mass was palpated posterior to the vagina which proved to be a newly diagnosed metastasized colon carcinoma. It is unlikely that this fetal loss was directly attributed to the cancer.

\section{DISCUSSION}

In this observational study, we report on a large series of patients with cancer diagnosed during pregnancy. The most remarkable finding is the observation that $54.2 \%$ of children were born preterm, with a subsequently high rate of admission to the NICU. In the vast majority (89.7\%), the delivery was iatrogenically induced. The complications of preterm birth are well studied and include intraventricular hemorrhage, bradycardia/apnea, need for respiratory assistance, necrotizing 
enterocolitis, sepsis, seizures, hypoglycemia, and feeding problems. Recently Bastek et $\mathrm{al}^{18}$ showed that late-preterm neonates (34 to 37 weeks) have significantly more medical complications compared with their full-term counterparts. In addition to these immediate effects, preterm birth is also associated with long-term morbidities and impaired cognitive and behavioral outcomes. ${ }^{19}$ In this study, neonatal problems were mainly due to iatrogenic, and therefore preventable, prematurity. Prematurity can be prevented by postponing or continuing treatment until a term delivery can be obtained.

Deliberate delay of therapy to achieve fetal maturity appears to be a safe option for patients with early-stage disease. For early-stage breast cancer, Cold et $\mathrm{al}^{20}$ described the outcomes of a series of 7,501 patients and concluded that there was no evidence for a survival benefit due to early initiation of adjuvant chemotherapy within the first 2 to 3 months after surgery. Nettleton et $\mathrm{al}^{21}$ presented a mathematical model to quantify the risk of axillary nodal metastases as a result of delayed treatment of breast cancer during pregnancy. They calculated that the daily increased risk of axillary metastases as a result of treatment delay is $0.028 \%$ for tumors with moderate doubling times of 130 days and $0.057 \%$ for tumors with rapid doubling times of 65 days. They concluded that this minimal maternal risk may be acceptable to some third-trimester pregnant women with early breast cancer. $^{21}$ Duggan et $\mathrm{al}^{22}$ described planned delay in patients with stage IA and IB cervical cancer with a mean diagnosis-to-treatment interval of 144 days (range, 53 to 212 days). All these patients were free of disease after a median follow-up of 23 months.

Continuation of treatment started during pregnancy is a second way to prevent prematurity. To date, treatment during pregnancy is continued until fetal viability is reached. Instead, fetal maturity should preferably be the criterion to induce delivery. In a multidisciplinary setting, a maximal effort should be made to delay delivery until at least 35 to 37 weeks.

Malformations that were reported in this study are also seen in a normal population. Furthermore, the incidence was not increased. These observations confirm the notion that cytotoxic treatment administered after the first trimester of pregnancy, the period of embryogenesis, does not result in a higher incidence of congenital malformations. ${ }^{4,6-9,23}$

Two children born 10 days after high-dose chemotherapy for acute lymphatic leukemia developed a neutro/pancytopenia. Neonatal bone marrow insufficiency after prenatal chemotherapy exposure was described previously. ${ }^{4,24}$ The hematologic toxicity in the two children suggests that a considerable fraction of these drugs passes through the placenta. In literature on cancer treatment during pregnancy, growth restriction is a permanent concern ${ }^{4,24,25}$ which is confirmed by the findings in this study. The largest proportion of small-for-gestational-age children was seen in patients with hematologic tumors.

Ring et $\mathrm{al}^{6}$ described a series of pregnant women with breast cancer treated with chemotherapy during pregnancy. Data on birth weight were available in 17 children, and they were all above the 10th percentile for gestational age. Also in this study, the birth weight in breast cancer patients receiving chemotherapy in pregnancy was within normal ranges ( 4 of 34 children had a birth weight below 10th percentile of gestational age). Since small-for-gestational-age children were observed only in mothers with certain tumor types such as hematologic tumors but not in mothers with breast cancer, the data suggest that an impact on fetal growth might be related to specific cancer types and treatments. Whether the effect is determined by the maternal illness that is associated with malnutrition and a catabolic status, ${ }^{26}$ or by direct or indirect effects of the treatment remains an unanswered question.

Patients receiving chemotherapy had an increased risk of preterm labor. However, the time interval between the administration of chemotherapy and the onset of contractions varied substantially. The underlying mechanism is unclear. Physical or psychological stress can induce preterm labor through activation of the maternal hypothalamic-pituitary-adrenal axis; ${ }^{27-29}$ thus, the stress associated with cancer diagnosis and treatment may contribute. Alternatively, fetal stress or uteroplacental vasculopathy may activate the fetal hypothalamic-pituitary-adrenal axis and induce labor. ${ }^{30}$ The potential role of chemotherapy in preterm labor needs additional investigation. Apoptosis in amnion epithelial and chorion trophoblast layers of fetal membranes is known as an important factor in the pathogenesis of membrane rupturing. ${ }^{31,32}$ This process theoretically might be facilitated by exposure to chemotherapy.

It is accepted that interruption of pregnancy is indicated in instances of a poor maternal prognosis or when there is an urgent need for cytotoxic treatment in the first trimester. ${ }^{4,13,25}$ In this study, the main indication (in 29 of 30 patients) for pregnancy termination was a maternal malignancy. Seventeen of these pregnancies were diagnosed in the first trimester. Of the 13 pregnancies that were ended thereafter, eight had a poor maternal prognosis at diagnosis. One patient had a stage IB1 cervical cancer diagnosed at 15 weeks for which therapy during pregnancy is still considered experimental. In four patients, the pregnancy was terminated because of the need for oncologic treatment while, according to current knowledge, this was medically not strictly indicated. Surgical and medical treatment for breast cancer ( $\mathrm{n}=3$; T1-2 at 19, 20, and 22 weeks) and Hodgkin's disease ( $\mathrm{n}=1 ; 20$ weeks) is possible during pregnancy. The fact that three of these four instances of pregnancy termination were treated in the same city emphasizes the need for sufficient information and education on this topic.

The most frequently encountered tumor types were breast cancer, hematologic malignancies, skin cancer, and cervical cancer. The frequencies follow the distribution of cancer in the general population in this age group (20 to 40 years) in this area. ${ }^{33}$ Other studies on cancer during pregnancy described proportionally more cervical cancers (maximum of $15 \%$ ), malignant melanomas (maximum of $31 \%$ ), or thyroid cancer. ${ }^{11,13,34}$ Differences in inclusion criteria and regional differences in incidence, sensitization campaigns, and screening programs might explain the difference between our study and others. Because tumor distribution is comparable to that in the nonpregnant population of that age group, we can conclude that the concurrence of cancer and pregnancy most likely reflects the patients's age (mean age of 33 years).

An important strength of this study is that a large series of only invasive cancers diagnosed during pregnancy was included (excluding preinvasive and postpartum diagnoses). Furthermore, the interpretation of the birth weight was adjusted for gestational age and sex. Limitations to our study include the absence of centralized national registries for the entity "cancer and pregnancy." Second, there is no separate registration for termination of pregnancy in most hospitals. Therefore, we can assume an under-registration of the early pregnancies that miscarried or were interrupted. 
The findings of this study show an overall good outcome of pregnancies complicated with cancer. However, a high rate of preterm labor induction with a subsequent high rate of admission of infants to the NICU was observed. Interdisciplinary decision making on the timing of delivery by obstetricians and neonatologists is necessary. Preferably, delivery should not be induced before 35 to 37 weeks. Current data confirm that cytotoxic treatment administered during the second and third trimesters of pregnancy does not increase the rate of congenital malformations.

\section{AUTHORS' DISCLOSURES OF POTENTIAL CONFLICTS OF INTEREST}

The author(s) indicated no potential conflicts of interest.

\section{AUTHOR CONTRIBUTIONS}

Conception and design: Kristel Van Calsteren, Frédéric Aman Provision of study materials or patients: Kristel Van Calsteren, Frank De Smet, Liesbet Van Eycken, Mina Mhallem Gziri, Willemijn Van Gemert, Michael Halaska, Ignace Vergote, Nelleke Ottevanger, Frédéric Amant Collection and assembly of data: Kristel Van Calsteren, Liesbeth Heyns, Mina Mhallem Gziri, Willemijn Van Gemert, Michael Halaska, Nelleke Ottevanger, Frédéric Amant

Data analysis and interpretation: Kristel Van Calsteren, Frank De Smet, Nelleke Ottevanger, Frédéric Amant

Manuscript writing: Kristel Van Calsteren, Frédéric Amant Final approval of manuscript: Kristel Van Calsteren, Liesbeth Heyns, Frank De Smet, Liesbet Van Eycken, Mina Mhallem Gziri, Willemijn Van Gemert, Michael Halaska, Ignace Vergote, Nelleke Ottevanger, Frédéric Amant

\section{REFERENCES}

1. Ní Mhuireachtaigh $R$, O'Gorman DA: Anesthesia in pregnant patients for nonobstetric surgery. $\mathrm{J}$ Clin Anesth 18:60-66, 2006

2. Moran BJ, Yano H, Al Zahir N, et al: Conflicting priorities in surgical intervention for cancer in pregnancy. Lancet Oncol 8:536-544, 2007

3. Briggs GG, Freeman RK, Yaffe SJ: Drugs in Pregnancy and Lactation. Philadelphia, PA, Lippincott Williams \& Wilkins, 2008

4. Cardonick $E$, lacobucci $A$ : Use of chemotherapy during human pregnancy. Lancet Oncol 5:283291, 2004

5. Kal HB, Struikmans H: Radiotherapy during pregnancy: Fact and fiction. Lancet Oncol 6:328333, 2005

6. Ring $A E$, Smith IE, Jones A, et al: Chemotherapy for breast cancer during pregnancy: An 18-year experience from five London teaching hospitals. J Clin Oncol 23:4192-4197, 2005

7. Mir O, Berveiller P, Ropert S, et al: Emerging therapeutic options for breast cancer chemotherapy during pregnancy. Ann Oncol 19:607-613, 2008

8. Avilés $\mathrm{A}$, Neri $\mathrm{N}$ : Hematological malignancies and pregnancy: A final report of 84 children who received chemotherapy in utero. Clin Lymphoma 2:173-177, 2001

9. Hahn KM, Johnson PH, Gordon N et al: Treatment of pregnant breast cancer patients and outcomes of children exposed to chemotherapy in utero. Cancer 107:1219-1226, 2006

10. Pavlidis NA: Coexistence of pregnancy and malignancy. Oncologist 7:279-287, 2002

11. Stensheim H, Moller B, van Dijk $T$, et al: Cause-specific survival for women diagnosed with cancer during pregnancy or lactation: A registrybased cohort study. J Clin Oncol 27:45-51, 2009

12. Belgian Cancer Registry: Yearly statistics. http://www.kankerregister.org/
13. Pereg $D$, Koren $G$, Lishner $M$ : Cancer in pregnancy: Gaps, challenges and solutions. Cancer Treat Rev 34:302-312, 2008

14. Goldenberg RL, Culhane JF, lams JD, et al: Epidemiology and causes of preterm birth. Lancet 371:75-84, 2008

15. Queisser-Luft A, Stolz G, Wiesel A, et al: Malformations in newborn: Results based on 30,940 infants and fetuses from the Mainz congenital birth defect monitoring system (1990-1998). Arch Gynecol Obstet 266:163-167, 2002

16. Drew JH, Parkinson P, Walstab JE, et al: Incidences and types of malformations in newborn infants. Med J Aust 1:945-949, 1977

17. Merks JH, van Karnebeek CD, Caron HN, et al: Phenotypic abnormalities: Terminology and classification. Am J Med Genet A 123A:211-230, 2003

18. Bastek JA, Sammel MD, Pare $E$, et al: Adverse neonatal outcomes: Examining the risks between preterm, late preterm, and term infants. Am J Obstet Gynecol 199:367-368, 2008

19. Johnson S: Cognitive and behavioural outcomes following very preterm birth. Semin Fetal Neonatal Med 12:363-373, 2007

20. Cold S, During M, Ewertz M, et al: Does timing of adjuvant chemotherapy influence the prognosis after early breast cancer? Results of the Danish Breast Cancer Cooperative Group (DBCG). $\mathrm{Br} J$ Cancer 93:627-632, 2005

21. Nettleton J, Long J, Kuban D, et al: Breast cancer during pregnancy: Quantifying the risk of treatment delay. Obstet Gynecol 87:414-418, 1996

22. Duggan $B$, Muderspach $L I$, Roman LD, et al: Cervical cancer in pregnancy: Reporting on planned delay in therapy. Obstet Gynecol 82:598-602, 1993

23. Larsen WJ: Human Embryology. Philadelphia, PA, Churchill Livingstone, 2001

24. Fischer D, Ahr A, Schaefer B, et al: Outcome of preterm and term neonates of mothers with malignant diseases diagnosed during pregnancy. J Matern Fetal Neonatal Med 19:101-103, 2006
25. Weisz B, Schiff E, Lishner M: Cancer in pregnancy: Maternal and fetal implications. Hum Reprod Update 7:384-393, 2001

26. Nulman I, Laslo D, Fried S, et al: Neurodevelopment of children exposed in utero to treatment of maternal malignancy. Br J Cancer 85:1611-1618, 2001

27. Wadhwa $P D$, Sandman $C A$, Porto $M$, et al: The association between prenatal stress and infant birth weight and gestational age at birth: A prospective investigation. Am J Obstet Gynecol 169:858865, 1993

28. Dole N, Savitz DA, Hertz-Picciotto I, et al: Maternal stress and preterm birth. Am J Epidemio 157:14-24, 2003

29. Glynn LM, Schetter CD, Hobel CJ, et al: Pattern of perceived stress and anxiety in pregnancy predicts preterm birth. Health Psychol 27:43-51, 2008

30. Arias F, Rodriquez L, Rayne SC, et al: Maternal placental vasculopathy and infection: Two distinct subgroups among patients with preterm labor and preterm ruptured membranes. Am J Obstet Gynecol 168:585-591, 1993

31. Lei $H$, Furth $E E$, Kalluri $R$, et al: A program of cell death and extracellular matrix degradation is activated in the amnion before the onset of labor. J Clin Invest 98:1971-1978, 1996

32. McLaren J, Taylor DJ, Bell SC: Increased incidence of apoptosis in non-labour-affected cytotrophoblast cells in term fetal membranes overlying the cervix. Hum Reprod 14:2895-2900, 1999

33. Henau K, Renard F, De Gendt C: Cancer Incidence in Belgium 2004-2005. Belgian Cancer Registry D/2008/11.846/1, Brussels, 2008

34. Smith LH, Danielsen B, Allen ME, et al: Cancer associated with obstetric delivery: Results of linkage with the California Cancer Registry. Am J Obstet Gynecol 189:1128-1135, 2003 